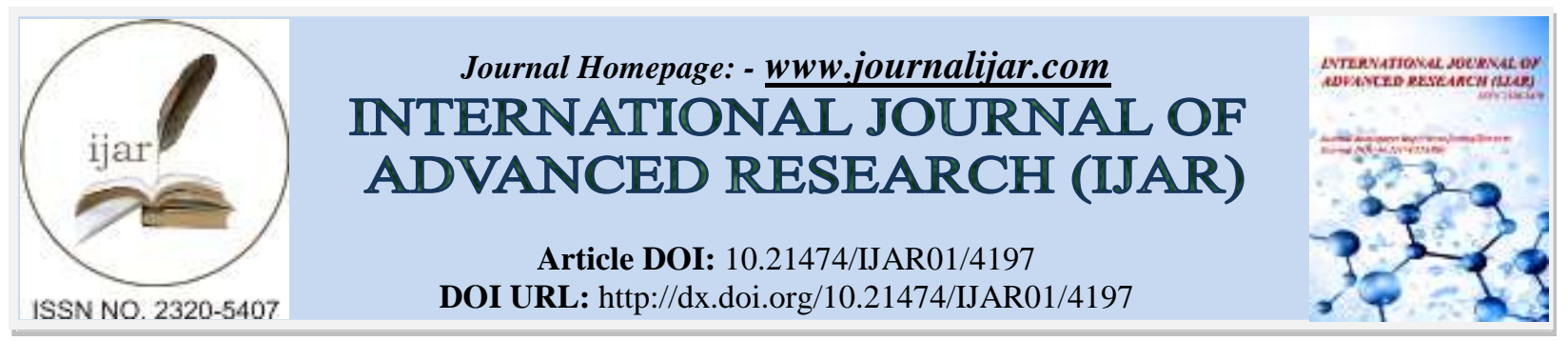

RESEARCH ARTICLE

\title{
A STUDY ON DEVELOPING VALID E-SERVICE QUALITY SCALE FOR ONLINE SHOPPING.
}

\section{Mr. Bhautik Shah ${ }^{1}$ and Dr. Keyur Nayak ${ }^{2}$.}

1. Research Scholar Pacific University, Udaipur.

2. Director, Laxmi Institute of Management, Sarigam.

\section{Manuscript Info}

Manuscript History

Received: 17 March 2017

Final Accepted: 10 April 2017

Published: May 2017

Key words:-

Service Quality, Responsiveness,

Consumer Marketing, Service

Differentiation, Personalization, Trust

\begin{abstract}
This paper develops a research model to examine the relationship among e-service quality dimensions and overall service quality. The purpose of this paper is to design, develop and evaluate a reliable and valid scale for the measurement of online retail service quality. Data from a survey of 100 online consumers were used to test the research model. E-service quality is the difference between customer's expectations for service performance priorities the service encounters and their expectations about service performance prior to the service offering. Confirmatory factor analysis was conducted to examine the reliability and validity of the measurement model. A Seven-factor instrument has been proposed to measure the e-service quality. The analytical results showed that the dimensions of web site design, reliability, responsiveness, reliability, Information Quality, Product Quality, Security and trust affect overall service quality and customer satisfaction. However, the personalization dimension is not significantly related to overall service quality and customer satisfaction. This study suggests that to enhance customer purchase intentions, online stores should develop marketing strategies to better address the trustworthiness, reliability, and responsiveness of web-based services. Online stores can devote valuable corporate resources to the important e-service quality attributes identified by this study.

This study developed the instrument dimensions of e-service quality by modifying the SERVQUAL model to consider online shopping context. Moreover, the results of this study provide a valuable reference for managers of online stores, as well as for researchers interested in internet marketing.
\end{abstract}

Copy Right, IJAR, 2017,. All rights reserved.

\section{Introduction:-}

With the rapid global growth in electronic commerce (e-commerce), businesses are attempting to gain a competitive advantage by using e-commerce to interact with customers. Businesses with the most experience and success in using e-commerce are beginning to realize that the key determinants of success or failure are not merely web site presence and low price but also include the electronic service quality (e-service quality) (Yang, 2001; Zeithaml, 2002). 
Understanding the determinants of service quality, customer satisfaction and purchase intentions for online shopping is important for both marketing researchers and online stores managers. Moreover, previous studies have revealed that service quality in online environments is an important determinant of the effectiveness of e-commerce (Yang, 2001; Janda et al., 2002).

To prove the usefulness of the research model, data were collected from 297 online consumers. Confirmatory factor analysis (CFA) was conducted to examine the reliability and validity of the measurement model, and the structural equation modeling (SEM) technique was used to test the research model. The test results provide a valuable reference for managers of online stores, as well as for researchers interested in internet marketing.

The techniques of measuring service quality have become a major area in the marketing literature during the past few decades since the increasing importance of service industry. The share of service industry in the economy has been increasing for years. Increasing competition in the service industry has led many companies to consider service quality as a strategic tool. As well as service quality, e-service quality has been becoming more important nowadays. Measuring e-service quality was highly developed after 2000s with the increasing usage amount of e-services. The researches about measuring and improving e-service quality have been continuing sharply.

There have been many studies that developed scales and dimensions for measuring service and e-service quality in the literature. The first model for measuring service quality was developed by Grönroos in 1984 (Dotchin and Oakland, 1994; Seth et al., 2005; Bulbul and Demirer, 2008). He developed a service quality model and measured perceived service quality. Technical quality, functional quality, and corporate image were used in the model as the dimensions of service quality. Technical quality is about customer evaluations about the service delivered. Functional quality is seen to be more important dimension than technical quality. It refers how consumers take the service and it is the important variable for consumer perceptions and service differentiation. Technical quality is interested in what was delivered such as the knowledge about product and services whereas functional quality is interested in how the service was delivered such as the importance of the service personnel manners. Corporate image has a positive impact on customer perceptions.

E-services are distinguished from traditional services in terms of their characteristics such as the cost structure of services, the high degree of outsourcing, the rapid development of new services, the availability of transparent service feedback, and the continuous improvement of services (Riedl et al., 2009). Because of these distinguished characteristics between services and e-services, measuring e-service quality is different from measuring traditional service quality. Before developing e-service quality scales, the research have concentrated on determining three points such as technical quality of websites, the factors that influence e-satisfaction, and service quality of websites (Akinci et al., 2009). Hence, the criteria that should be used for designing an effective website have been the focus points of researchers. Abels et al. (1999) determined the six criteria that website designers need to use for designing a successful website: 1) use - easy to use, 2) content - having useful information, 3) structure - displaying of website, 4) linkage - providing link to the information at the website and other websites, 5) search - providing search button in website itself, 6) appearance - being attractive.

With the increasing competition in e-commerce, it becomes imperative for online retailers to examine and study customer's attitude toward online shopping (Zhou et al., 2007).

If marketers know how online customers make their decisions, they can adjust their marketing plan to make it successful in attracting and retaining customers. Despite the many studies that have been dedicated to online shopping attitude in different parts of the world, there is still lack of studies on online shopping attitude in certain countries and cultures. Osman et al. (2010) stated that, "Further studies should explore other factors that influence attitude towards online purchasing." As a result, some researchers claimed that little information is known regarding customers' attitude towards e-shopping and the factors impacting their attitude in developing countries. (Haque et al., 2006).

\section{Literature Review:-}

Zeithaml et al. (2002) showed that a number of studies have examined some criteria that identified customers' evaluations about website quality. These are information availability and content; ease of use; privacy/security; graphic style; fulfillment/reliability; and other criteria such as access, responsiveness, personalization. They developed e-SERVQUAL in 2002 for measuring e-service quality. This model has been conceptualized in two parts: 
core e-service quality scale with four dimensions such as efficiency, reliability, fulfillment, privacy; and recovery eservice quality scale with three dimensions such as: responsiveness, compensation, contact.

Another scale for assessing service quality of e-tailers was developed as PIRQUAL - Perceived Internet Retail Quality Model (Francis and White, 2002). The scale consists of six dimensions such as web store functionality, product attribute description, ownership conditions, delivery, customer service, and security.

Parasuraman et al. (2005) proposed E-S-QUAL and E-RecS-QUAL scales for measuring e-service quality. E-SQUAL is a core service quality scale for measuring core service attributes of websites and E-RecS-Qual is an erecovery service quality scale which measures the quality of recovery services provided by websites. These scales which adapt to psychometric properties are reliable and valid scales. The E-S-QUAL scale has 22 items and four dimensions such as efficiency, fulfillment, system availability, and privacy. E-RecS-QUAL contains 11 items in three dimensions: responsiveness, compensation, and contact. E-S-QUAL scale is a leading model for the measurement of e-service quality just as SERVQUAL in service quality.

Existing e-service quality scales were seen as goal oriented and utilitarian-based by Bauer et al. (2006). They suggested that utilitarian and hedonic e-service quality dimensions should be integrated; hence they developed eTransQual scale. It is a transaction process based approach to integrate utilitarian and hedonic elements in measuring e-service quality. This scale has 25 items and five dimensions such as: functionality/design, enjoyment, process, reliability, and responsiveness.

Chau et al. (2006) Although online shopping is evidenced to have high potential in Malaysia, there is still lack of understanding on the subject matter and its effect on consumer marketing is still unknown.

Alqahtani et al. (2012) listed the top influential factors on the e-commerce success in Saudi Arabia from the perspective of the consumer. The list included efficient delivery, e-commerce online presence, effective warranty agreements, a trial of tangible product experience and installing high quality security systems with strong encryption algorithms for the prevention of hacking and fraud. These factors were discussed by the authors are part of e-service quality construct which requires enhancement to attract Saudi consumers to purchase online.

The perceived e-service quality is again assessed by the consumer in terms of both procurement and distribution of the service provided by the company as well as to what degree the expectations of the consumers are fulfilled by the service outputs after distribution (Grönroos, Helnonen, Isonlemi \& Lindholm, 2000).

The most distinctive difference between electronic service quality and traditional service quality is that interpersonal interaction is replaced by human-machine interaction. This simple difference has lead to the necessity of evaluating different dimensions in order to assess service quality in terms of e-commerce (Hapenciuc and Condratov, 2007).

(Madu And Madu 2002) Proposed The Following 15 Dimensions Of Online Service Quality Based On Literature Review: Performance, Features, Structure, Aesthetics, Reliability, Storage Capacity, Serviceability, Security And System Integrity, Trust, Responsiveness, Product/Service Differentiation And Customization, Web Store Policies, Reputation, Assurance, And Empathy.

(Yang And Jun 2008) Measured E-Service Quality Using Two Groups: Internet Purchasers And Internet NonPurchasers. They Found That Reliability Was The Most Important Dimension For Internet Purchasers Even When Compared To Access, Ease Of Use, Personalization, Security, And Credibility.

(Li And Suomi 2009) Proposed Eight Dimensions Of E-Service Quality, Which Are: Website Design, Reliability, Responsiveness, Security, Fulfillment, Personalization, Information And Empathy.

\section{Research Approach:-}

Due to the constraints of a real-life evaluation in the current study, the service quality dimensions had to be simplified and adjusted for the survey. Thus, not all of the dimensions are included in the survey questionnaire. Based on the studies previously done, we selected the following seven dimensions: Reliability, Responsiveness, Information Quality, Security, Trust, Website Design and Product Quality. The "Personalization" dimension was 
emerged into the "Trust" dimension. Scale items for assessing these dimensions were incorporated into a survey instrument.

The design of research work was exploratory through convenience sampling technique. The data was collected with the help of survey using structured questionnaire.

Sampling: The sample size of 100 was collected from the people of Valsad District.

Objective of the study: is to validate main factors for service quality in online shopping to achieve the maximum service quality and customer satisfaction.

\section{Hypothesis}

Ho1 There is no correlation of various factors on the Service Quality in Online Shopping.

\section{Procedure for Data Collection:-}

The primary data was collected from respondents through personal interview based on structured questionnaire. The questionnaire was so prepared as to obtain and elicit the information required to study the various factors of Service Quality. The data was collected from people who prefer online shopping rather than offline shopping most of the time. The secondary data for the present study had been gathered from various journals, research papers, newsletters, books and internet websites.

\section{Tools of Data Analysis:-}

The Confirmatory Factor Analysis had been used on the collected data and analysis of the same had been done through SPSS AMOS Software to draw meaningful conclusions. After performing reliability test and determining the factors through Factor Analysis completing the field work the collected information was edited and tabulated. The conclusions were drawn on the basis of data collected, collated and summarized. The interpretation is based on those findings from the analysis.

\section{Significance of the Study:-}

The study results will be of a great help to entrepreneurs, sellers associated with online shopping websites and employees of the segments in the virtual market segment through which they can achieve maximum customer satisfaction by improvising their service quality based on the factors determined. It will also be useful to the customers who choose to prefer a selected website and products from many available websites.

\section{Data Analysis And Interpretation:-}

\section{Confirmatory Factor Analysis (CFA):-}

The Confirmatory factor analysis model is run through AMOS software. The CFA allows the researcher to test the hypothesis that a relationship between observed variable and the underlying latent constructs exists 
Fig No:- CFA for the measurement of Service Quality in Online Shopping

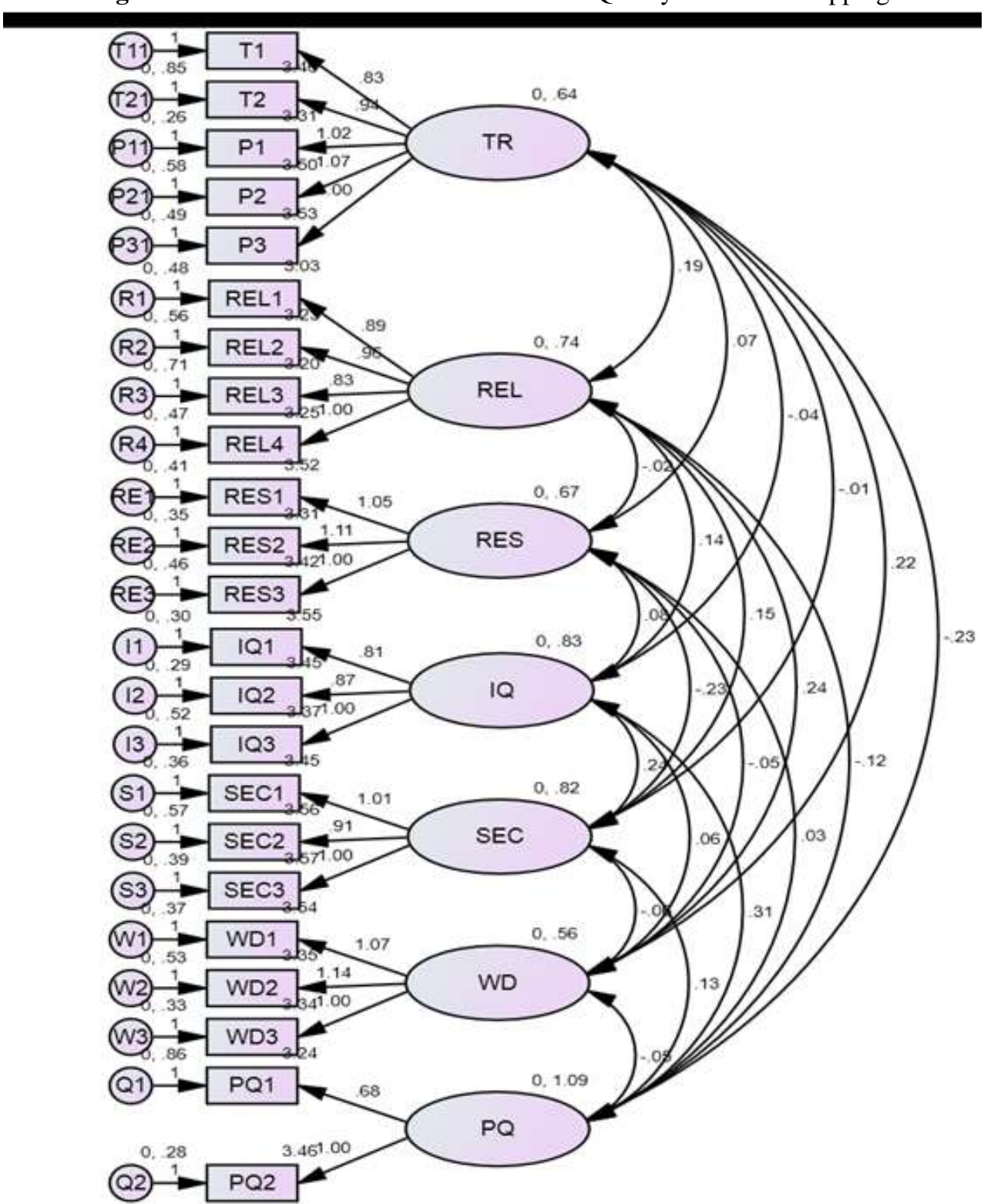

Table 1:- Convergent and Discriminant Validity Measures of Various Constructs of Service Quality in Online Shopping.

\begin{tabular}{|c|c|c|c|c|}
\hline Latent Constructs & CR & AVE & MSV & ASV \\
\hline Product Quality & 0.729 & 0.582 & 0.106 & 0.037 \\
\hline Trust & 0.844 & 0.524 & 0.130 & 0.050 \\
\hline Reliability & 0.819 & 0.532 & 0.137 & 0.051 \\
\hline Responsiveness & 0.845 & 0.646 & 0.094 & 0.021 \\
\hline Information Quality & 0.847 & 0.649 & 0.106 & 0.041 \\
\hline Security & 0.842 & 0.640 & 0.094 & 0.040 \\
\hline Website Design & 0.826 & 0.613 & 0.137 & 0.049 \\
\hline
\end{tabular}

The above table represents the convergent and discriminant validity measures of various constructs taken together in a confirmatory factor analysis. As shown in the results the composite reliability of each construct is more than 0.70 as well as greater than average variance extracted (AVE). This indicates the existence of the convergent validity in 
the instrument. In addition to this, average variance extracted of each construct is greater than MSV and ASV statistics which indicates the existence of discriminant validity of the instrument.

\section{Result (Default model)}

Minimum was achieved

Chi-square $=255.040$

Degrees of freedom $=209$

Probability level $=.016$

Table 2:- Goodness of Fit Statistic

\begin{tabular}{|l|l|l|}
\hline Goodness of Fit Model Index & Recommended Value* & Model \\
\hline Chi-square / degree of freedom (CMIN / df)** & $\leq 5.00$ & 1.22 \\
\hline Goodness of Fit Index (GFI) & $\geq 0.90$ & 0.828 \\
\hline Adjusted Goodness of Fit Index (AGFI) & $\geq 0.80$ & 0.773 \\
\hline Normalized Fit Index (NFI) & $\geq 0.90$ & 0.779 \\
\hline Comparative Fit Index (CFI) & $\geq 0.90$ & 0.949 \\
\hline Root Mean Square Error of Approximation (RMSEA) & $\leq 0.05$ & 0.047 \\
\hline
\end{tabular}

* These criteria's are according to Hair et al. (1998, 2010) and Arbuckle and Wothke (1995)

The score obtained from the analysis suggested an excellent fit between the data and model $(\chi 2=255.04, d f=209$, $\chi 2 / d f=1.22, \mathrm{GFI}=0.828, \mathrm{AGFI}=0.773, \mathrm{NFI}=0.779, \mathrm{CFI}=.949, \mathrm{RMSEA}=.047)$. Almost all the fit indices comply with the values recommended by Haire et al. (2010) and Arbuckle and Wothke (1995).

A confirmatory factor analysis was applied on the 100 variable Seven dimensional e-service quality scale determined with the explanatory factor analysis to study the structural validity of the scale. The CFA concludes that the value was significant $(255.04, \mathrm{p}<.000)$. Chi-square values are usually significant in large sample groups. For this reason it is recommended that the ratio of $\chi^{2} / \mathrm{df}$ is taken into consideration (Kavas, 2012). Accordingly it is observed that the ratio of $\chi 2 / \mathrm{df}(255.04 / 209=1.22)$ and is lesser than 5 and indicates an sufficient fit. At the same time the other goodness of fit indices obtained from the CFA show that the fit of the model is appropriate.

The results of the repeated CFA showed that the $\chi 2 / \mathrm{df}$ ratio $(255.04 / 209=1.22)$ was less than 5 which indicated an acceptable fit. Furthermore, the obtained goodness of fit indices indicate a sufficient fit level (RMSEA=.05, $\mathrm{CFI}=.94$, NFI=.78, GFI=.83, AGFI=.0.77). Although the values of $\mathrm{GFI}=.83$ and $\mathrm{AGFI}=.77$ are less than the proposed values the fact that the other values are of a sufficient ratio as well as the fact that the current values are close to the proposed values indicate that the fit is not poor (Engel, Moosbrugger, 2003; Tanhan and Şentürk, 2011; Ercan, 2011).

\section{Conclusions:-}

E-service quality is a new developing area, which has strategic importance for businesses striving to address consumers in the electronic market space (Hapenciuc, Condratov, 2007). E-services are carried out through various electronic methods such as the internet, E-Mail, mobile The studies of Parasuraman, Zeithaml \& Malhotra (2005) examined electronic service quality in two basic dimensions. Confirmatory (CFA) factor analyses were applied on the model in this study which endeavoured to determine the e-service quality dimensions of online shopping and to determine the impact of these dimensions on e-service quality and the impact of the e-service quality on the perceived value variable. Ho and Lee (2007) determined that the general dimensions of electronic service quality consisted of seven dimensions which were Information Quality, Security, Website Design, Reliability, Product Quality, Trust and Responsiveness.

In conclusion, all the factors have significant impact on overall service quality in online shopping. For this reason, the study results will be of a great help to entrepreneurs, sellers associated with online shopping websites and employees of the segments in the virtual market segment through which they can achieve maximum customer satisfaction by improvising their service quality based on the factors determined. It will also be useful to the customers who choose to prefer a selected website and products from many available websites. 


\section{References:-}

1. Yang, Z. (2001), "Customer perceptions of service quality in internet-based electronic commerce", Proceedings of the 30th EMAC Conference, Bergen, pp. 8-11.

2. Zeithaml, V.A. (2002), "Service excellent in electronic channels", Managing Service Quality,

3. Vol. 12 No. 3, pp. 135-8.

4. Janda, S., Trocchia, P.J. and Gwinner, K.P. (2002), “Customer perceptions of internet retail

5. service quality", International Journal of Service Industry Management, Vol. 13 No. 5,

6. pp. 412-31.

7. Dotchin, J. A. \& Oakland, J. S. (1994). Total quality management in services. International Journal of Quality \& Reliability Management, 11(3), 27-42.

8. Seth, N., Deshmukh, S. G., \& Vrat, P. (2005). Service quality models: a review. International Journal of Quality \& Reliability Management, 22(9), 913-949.

9. Bulbul, H. \& Demirer, O. (2008). Hizmet kalitesi ölçüm modelleri SERVQUAL ve SERPERF'in karşılaştırmalı analizi. Selçuk Üniversitesi SBE Dergisi, 20, 181-198.

10. Riedl, C., Leimeister, J. M. \& Krcmar, H. (2009). New service development for electronic services: A literature review. Proceedings of the Fifteenth Americas Conference on Information Systems (AMCIS), San Francisco.

11. Akinci, S., Inan, E. A., Aksoy, S. \& Buyukkupcu, A. (2009). Pazarlama literatüründe hizmet kalitesi kavramının dünü ve bugünü. Hacettepe Üniversitesi İ̈BF Dergisi, 27 (2), 61-82.

12. Abels, E. G., White, M. D. \& Hahn, K. (1999). A user-based design process for Web sites. OCLC Systems \& Services, 15 (1), 35-44.

13. Zeithaml, V. A., Parasuraman, A. \& Malhotra, A. (2002). Service quality delivery through web sites: a critical review of extant knowledge. Journal of the Academy of Marketing Science, 30(4), 362-375.

14. Parasuraman, A., Zeithaml, V. A. \& Malhotra, A. (2005). ES-QUAL a multiple-item scale for assessing electronic service quality. Journal of Service Research, 7(3), 213-233.

15. Francis, J. E. \& White, L. (2002). PIRQUAL: a scale for measuring customer expectations and perceptions of quality in internet retailing. In Proceedings of the 2002 American Marketing Association winter educators' conference: marketing theory and applications, 13, 263-70.

16. Bauer, H. H., Falk, T. \& Hammerschmidt, M. (2006). eTransQual: A transaction process-based approach for capturing service quality in online shopping. Journal of Business Research, 59(7), 866-875.

17. Osman, S., B.C. Yin-Fah and B.H. Choo, 2010. Undergraduates and Online Purchasing Behaviour. Asian Soc. Sci., 6: 133-146.

18. Zhou, L., L. Dai and D. Zhang, 2007. Online Shopping acceptance model: A critical survey of consumer factors in online shopping. J. Elect. Commer. Res., 8: 41-62.

19. Haque, A., J. Sadeghzadeh and A. Khatibi, 2006. Identifying potentiality online sales in Malaysia: A study on customer relationships online shopping. J. Applied Bus. Res. Fourth Quarter, 22: 119-130.

20. Chau, G., Q.D. Morris, R. Sopko, M.D. Robinson and O. Ryan et al., 2006. Identifying transcription factor functions and targets by phenotypic activation. Proc. Nat. Acad. Sci., 103: 12045-12050.

21. Alqahtani, M.A., A.H. Al-Badi and P.J. Mayhew, 2012. The enablers and disablers of e-commerce: Consumers' Perspectives. Electron. J. Inform. Syst. Dev. Countries, 54: 1-25.

22. Grönroos, C., Helnonen, F., Isonlemi, K., Lindholm, M. (2000). The Netoffer Model: A Case Example from the Virtual Marketspace, Management Decision, 38 (4), 243-252.

23. Hapenciuc, C.V., Condratov, I. (2007). Theoretical Frame for Quality Evaluation of Tourism-Related Websites Services, Economy Informatics, 1(4), 52-58.

24. Madu, C.N. and Madu, A.A. (2002). Dimensions of equality. International Journal of Quality \& Reliability Management, 19(3), 246-259.

25. Yang, Z. and Jun, M. (2002). Consumer perception of eservice quality: From internet purchaser and no purchaser perspectives. Journal of Business Strategies, 19(1), 19-41.

26. Li, H. and Suomi, R. (2009). A proposed scale for measuring e-service quality. International Journal of u- and e-service, Science and Technology, 2(1), 1-10.

27. Hair, J., Black, W., Babin, B. and Anderson, R. (2010). Multivariate Data Analysis. Upper Saddle River, NJ: Prentice-Hall.

28. Arbuckle, J.L. \& Wothke, W. (1995) AMOS 4.0: user's guide. United States of America: Small waters Corporation.

29. Kavas, A. B. (2012). Turkish Adaptation of Career Decision Scale: Validity and Reliability Study, Turkish Psychological Counseling and Guidance Journal, 4 (38),159-168. 
30. Engel, K.S., Moosbrugger, H., Müller, H. (2003) Evaluating the Fit of Structural Equation Models: Tests of Significance and Descriptive Goodness-of-Fit Measures, Methods of Psychological Research, 8 (2), 23-74.

31. Ercan, H. (2011) Psychometric Properties and The Adaptation Study of the Relational, Individual, Collective Self- Aspects Scale, KMÜ Journal of Social and Economic Researchs, 13 (21), 37-45.

32. Tanhan, F., Şentürk, E. (2011) Development of Teacher Attitude Scale Towards Undesirable Intraclass Behaviours of Students, Turkish Psychological Counseling and Guidance Journal, 4 (35), 44-53.

33. Hapenciuc, C.V., Condratov, I. (2007) Theoretical Frame for Quality Evaluation of Tourism-Related Websites Services, Economy Informatics, 1(4), 52-58.

34. Ho, C.I., Lee, Y.L. (2007) The Development of an E-travel Service Quality Scale, Tourism Management, 28, 1434-1449. 